\title{
Interstitial deletion at 11q14.2-11q22.1 may cause severe learning difficulties, mental retardation and mild heart defects in 13-year old male
}

\author{
Ioannis Papoulidis ${ }^{1 *}$, Vassilis Paspaliaris ${ }^{1}$, Elisavet Siomou' ${ }^{1}$, Sandro Orru², Roberta Murru ${ }^{2}$, Stavros Sifakis ${ }^{3}$,
} Petros Nikolaidis ${ }^{4}$, Antonios Garas ${ }^{5}$, Sotirios Sotiriou ${ }^{5}$, Loretta Thomaidis ${ }^{6}$ and Emmanouil Manolakos ${ }^{1,2}$

\begin{abstract}
Interstitial deletions of the long arm of chromosome 11 are rare, and they could be assumed as non-recurrent chromosomal rearrangements due to high variability of the size and the breakpoints of the deleted region. The exact region of the deletion was difficult to be determined before the use of molecular cytogenetic techniques such as array comparative genomic hybridization (aCGH). Here, a 13-year old boy with severe learning difficulties, mental retardation and mild heart defects is described. Conventional G-band karyotyping was performed and it is found that the patient is a carrier of a de novo interstitial deletion on the long arm of chromosome 11, involving 11 q14 and 11q22 breakpoints. Further investigation, using aCGH, specified the deleted region to 11q14.2-11q22.1. There was a difficulty in correlating the genotype with the phenotype of the patient due to lack of similar cases in literature. More studies should be done in order to understand the genetic background that underlies the phenotypic differences observed in similar cases.
\end{abstract}

\section{Background}

Terminal deletions of the long arm of chromosome 11 have been numerously described, and they are associated with Jacobsen syndrome (OMIM 147791) and characterized by thrombocytopenia, mental retardation, short stature, congenital heart defect, and characteristic facial dysmorphism [1,2]. On the contrary, interstitial deletions of the long arm of chromosome 11 are less common and often not fine-mapped, due to the similarity between band patterns (11q14 and $11 \mathrm{q} 22$ ) when conventional karyotype is performed $[3,4]$. So far, approximately 30 cases of $11 \mathrm{q}$ interstitial deletions have been reported [3-24]. Nevertheless, due to high variability of size and position of the deleted regions, phenotype-genotype correlations have been hard to evaluate due to the wide range of phenotypic features, ranging from normal to severe conditions including developmental delay/mental retardation, facial dysmorphisms and other medical implications.

\footnotetext{
* Correspondence: papoulidis@atg-labs.gr

'Access to genome P.C., Clinical Laboratory Genetics, 33A Ethn. Antistaseos str, 55134 Thessaloniki, Greece

Full list of author information is available at the end of the article
}

Moreover, before the introduction of molecular cytogenetic approaches, the resolution efficiency provided by conventional karyotype analysis jointly with the symmetric 11q banding pattern [3, 4], limited the accuracy of identification of breakpoints and precise deleted genomic regions.

\section{Case presentation}

The patient, a 13-year old boy, was the first and only child of unrelated healthy Caucasian parents. He was born by cesarean section after a full term pregnancy. Birth weight was $2,800 \mathrm{~g}$ ( $10^{\text {th }}$ percentile), length $50 \mathrm{~cm}\left(50^{\text {th }}\right.$ percentile) and head circumference $(\mathrm{HC})$ $35.5 \mathrm{~cm}\left(50^{\text {th }}\right.$ percentile). Neonatal and infancy periods were uneventful; nevertheless his motor development was delayed as he did not sit independently until the age of 15 months or walk unaided until the age of 22 months.

At the age of 5, language delay was observed and laboratory investigation was performed, including audiogram, biochemical and thyroid tests, which proved normal. He received speech therapy for a two-year period and his language difficulties resolved. He attended mainstream 
primary school with extra educational support and finished this level at the age of 12 years. At the age of 13 years he was referred for full developmental assessment because he was experiencing severe learning difficulties in secondary school. Upon physical examination, he was characterized as quite a sociable child, with mild dysmorphic facial features such as almond shaped eyes, hypertelorism, anteverted nostrils, and gothic palate. His weight at the time was $49 \mathrm{~kg}$ ( $40^{\text {th }}$ percentile), height $160 \mathrm{~cm}\left(60^{\text {th }}\right.$ percentile) and HC $54 \mathrm{~cm}\left(25^{\text {th }}\right.$ percentile). Upon neurological examination, he showed mild motor delay with severe clumsiness but without focal neurological signs. Ophthalmologic examination was normal. Heart auscultation revealed a mild systolic murmur.

Upon developmental evaluation, he was found to function at the mental level of a 10-year old. His cognitive abilities, according to the Wechsler Intelligence Scale for Children test (WISC III), were assessed as borderline, as his full-scale score was 75 with verbal score 75 and performance score 80.

Extensive laboratory investigation followed, including brain magnetic resonance imaging (MRI), electroencephalogram, kidney-liver- spleen ultrasound, bone age, biochemical tests, blood and urine amino acids, organic acids, very low fatty acids, thyroid function, ACTH, FSH, LH, DHEA-S, prolactin, estradiol e2, progesterone, testosterone, $17 \mathrm{a}-\mathrm{OH}$ progesterone and IGF-1, all proved normal. Heart ultrasound showed mild mitral valve prolapsed.

\section{Material and methods}

Metaphase chromosomes were obtained from phytohemagglutinin (PHA)-stimulated peripheral blood lymphocytes and high resolution (thymidine treatment) G-banding karyotype analysis was performed, using standard procedures. The conventional cytogenetic analysis revealed a de novo interstitial deletion on the long arm of chromosome 11, involving 11q14 and 11q22 breakpoints (Fig. 1).

To further investigate the specific finding, array-CGH was performed by hybridizing the sample against a male human reference commercial DNA sample (Promega biotech) using an array-CGH platform that includes 60000 oligonucleotides distributed across the entire genome (Agilent Technologies). The statistical test used as parameter to estimate the number of copies was ADAM-2 (provided by the DNA analytics software, Agilent Techn) with a window of $0.5 \mathrm{Mb}, \mathrm{A}=6$. Only those copy number changes that affected at least 5 consecutive probes with identically oriented change were considered as Copy Number Variations (CNV). As a consequence, for the majority of the genome, the average genomic power of resolution of this analysis was 200 kilobases.

Array-CGH analyses detected an interstitial deletion spanning region 11q14.2-11q22.1, genomic coordinates chr11: 85,702,633-97,854,695 (Genomic coordinates are listed according to genomic build GRCh37/hg19). No additional pathogenetic Copy Number Variations (CNVs) were detected and thus the molecular karyotype was: arr 11q14.2q22.1 (85702633-97854695)x1 (Fig. 2). The specific deletion contains approximately $12,15 \mathrm{Mb}$ of genomic material and includes 30 OMIM listed genes (Table 1 and Fig. 3).

\section{Discussion}

Here we report a patient with a de novo $12.15 \mathrm{Mb}$ interstitial deletion of chromosome 11 long arm, spanning from nt85702633 to nt97854695, exhibiting developmental delay, borderline mental retardation, severe speech delay, and
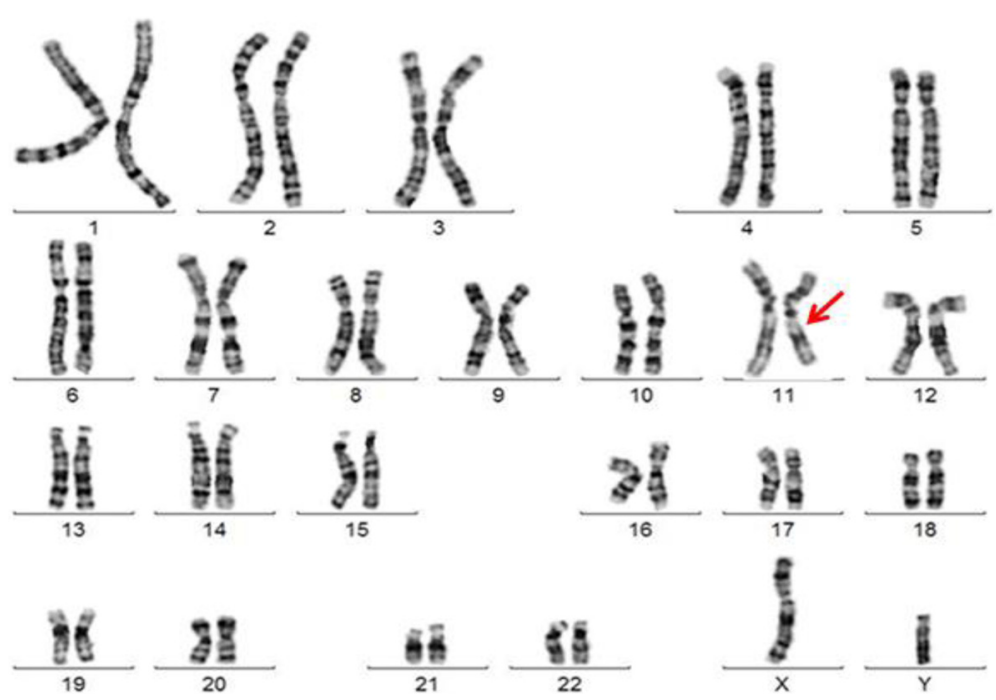

Fig. 1 G-banding karyotype of the patient. It is illustrated the interstitial deletion on the long arm of chromosome 11 


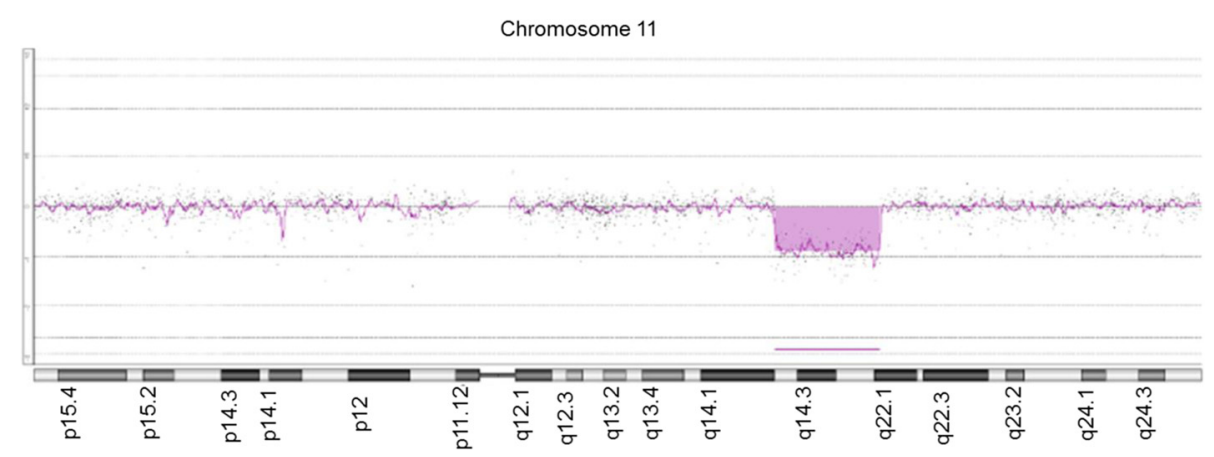

Fig. 2 Ideogram of the deleted region as it is detected using array CGH. The interstitial deletion is at 11q14.2-11q22.1

some dysmorphic features. The genotype of the patient was compared to 19 previously described patients carrying overlapping interstitial deletions of chromosome 11 long arm (Fig. 4). Cases with uncertain or not accurately defined breakpoints were not considered [4, 5, 13, 24].

Regarding these 19 cases, only six studies [9-12, 25, 26] were conducted using molecular cytogenetic techniques, such as a-CGH analysis with BAC clones or high-density oligonucleotide probes. In the remaining cases, conventional karyotype analysis and/or fluorescence in situ hybridization analysis was performed in order to define the position and size of the deletions. Table 2 summarizes the genotypes and phenotypic features of the present case and of the 19 cases with overlapping interstitial deletions of chromosome 11 long arm.

As listed in Table 2, most of the patients with an overlapping deletion of this region had mild to severe developmental delay, short stature/growth delay, high narrow palate or cleft palate/lip with or without migrognathia, and minor digital anomalies. Other clinical features include skeletal anomalies, brain anomalies, cranial dysmorphisms (microcephaly, trigonocephaly), retinal dysgenesis/exudative vitroretinopathy (EVR), genital anomalies, kidney anomalies and heart defects [7, 10, 11, 13, 19]. Regarding the present case with the exception of hypertelorism, and gothic palate our patient had none of these features.

However it is obvious (Table 2) that there are two cases, both without phenotypic abnormalities or developmental delay, which carry similar deletion with the present case. Li et al. [8] described five cases of 11q14.3-q21 deletion transmitted through three-generation kindred. The proband showed short stature and mild attention deficit disorder that required teaching assistant, all other family members were healthy despite carrying the deletion. The deleted region was mapped by FISH with overlapping BAC clones. The entire contig spans $3,6 \mathrm{Mb}$, and the breakpoints are within clones RP11-792 M23 and RP11-573 M3. In this region there are few genes and only two (MTNBR1 and NAALAD) are single copy genes. Other genes in this region have at least one copy present elsewhere in the genome that might compensate for the deleted copies of these genes.

Goumy et al. [6] described three cases of 11q14.3q22.1 deletion transmitted in three-generation kindred. The proband, a normal girl without dysmorphic features, was tested during mother's pregnancy by genetic amniocentesis because of a positive Down syndrome maternal serum screening test at 15 weeks gestation. The deletion was identified in the mother, who had toe camptodactyly and ophthalmologic disorders, and in the phenotipically normal grandfather. The minimal deletion size, mapped by combining $\mathrm{CGH}$ analysis and FISH with BAC clones was $8.5 \mathrm{Mb}$ from RP11-372E19 to RP11-775E2. This region contains almost 17 genes in common with those of our case. There might be other genes with similar functions located elsewhere in the genome. Another hypothesis that could explain the lack of phenotypic abnormalities was the haplosufficiency: the adequate functioning of the genes of this region in single copy. Both paternal and maternal origin in the transmission of the deletion, excluded genetic imprinting as explanation of the normal phenotype.

Present case differs from these cases for the presence of $11 q 14.2$ cytogenetic region, exactly from nt $85,668,485$ to the first absent BAC clone in case described by Li et al. [8] approximately near the nt $89,255,000$. In this region there are genes that should be responsible for the phenotype of this patient. Among the genes contained in the region, GRM5 (Glutamate receptor, metabotropic 5 gene OMIM604102) is particularly interesting. Metabotropic glutamate receptors (mGluRs) are G protein-coupled receptors (GPCRs) which transduce signals from the extracellular matrix to the cytoplasm by activating $G$ proteins. One prominent action of group I mGluRs is to protect neurons from apoptotic death [27].

GRM5 plays an important role in modulating neural activity and plasticity $[28,29]$. Its signaling is required for different forms of adaptive learning because impaired receptor function results in inappropriate retention of aversive memories, which seems to be related with impaired long-term potentiation in CA1 region and dentate gyrus of 
Table 1 OMIM listed genes included in the 11q14.2-11q22.1 region

\begin{tabular}{|c|c|c|c|c|c|c|}
\hline Gene & OMIM & Start & End & $\begin{array}{l}\text { Cytogenetic } \\
\text { region }\end{array}$ & Description & Protein function \\
\hline PICALM & 603025 & 85668485 & 58750108 & $11 q 14.2$ & $\begin{array}{l}\text { Phosphatidylinositol binding } \\
\text { clathrin assembly protein }\end{array}$ & $\begin{array}{l}\text { Involved in cellular trafficking, regulation of } \\
\text { endocytosis, and clathrin-mediated vesicle formation }\end{array}$ \\
\hline EED & 605984 & 85955815 & 85989781 & $11 q 14.2$ & $\begin{array}{l}\text { Embryonic ectoderm } \\
\text { development }\end{array}$ & $\begin{array}{l}\text { Mediates repression of gene activity through histone } \\
\text { deacetylation }\end{array}$ \\
\hline ME3 & 604626 & 86152150 & 86383678 & $11 q 14.2$ & $\begin{array}{l}\text { Malic enzyme 3, NADP(+)- } \\
\text { dependent, mitochrondrial }\end{array}$ & $\begin{array}{l}\text { Catalyzes the oxidative decarboxylation of malate } \\
\text { to pyruvate using either NAD+ or NADP+ as a cofactor }\end{array}$ \\
\hline FZD4 & 604579 & 86656721 & 86666433 & $11 q 14.2$ & $\begin{array}{l}\text { Frizzled homolog } 4 \\
\text { (Drosophila) }\end{array}$ & Receptor for Wnt proteins \\
\hline RAB38 & 606281 & 87846431 & 87908599 & $11 q 14.2$ & $\begin{array}{l}\text { RAB38, member RAS } \\
\text { oncogene family }\end{array}$ & May be involved in melanosomal transport and docking \\
\hline CTSC & 602365 & 88026760 & 88070941 & $11 q 14.2$ & Cathepsin C & $\begin{array}{l}\text { Lysosomal protease capable if removing dipeptides from } \\
\text { the amino terminus of protein substrates }\end{array}$ \\
\hline GRM5 & 604102 & 88237744 & 88796816 & $11 q 14.2$ & $\begin{array}{l}\text { Glutamate receptor, } \\
\text { metabotropic } 5\end{array}$ & $\begin{array}{l}\text { Transduce signals from extra cellular transmitters to the } \\
\text { inside of the cell by activating } G \text { proteins }\end{array}$ \\
\hline TYR & 606933 & 88911040 & 89028927 & $11 q 14.3$ & $\begin{array}{l}\text { Tyrosinase (oculocutaneous } \\
\text { albinismIA) }\end{array}$ & Conversion of tyrosine to melanin \\
\hline NOX4 & 605261 & 89057521 & 89231363 & $11 q 14.3$ & NAPDH pxidase 4 & $\begin{array}{l}\text { may function as catalytic component of an endothelial } \\
\text { NAPDH oxidase/may fulfill the function of oxygen sensor } \\
\text { in the kidney }\end{array}$ \\
\hline FOLH1B & 609020 & 89392465 & 89431886 & $11 q 14.3$ & Folate hydrolase 1B & $\begin{array}{l}\text { hydrolyzes beta-citrylglutamate/ found in the CNS during } \\
\text { pre-perinatal periods of development in the testis in adult males }\end{array}$ \\
\hline TRIM49 & 606124 & 89530823 & 89541743 & $11 q 14.3$ & Tripartite motif containing 49 & Protein-protein interaction. Expressed mostly in testis \\
\hline NAAIAD2 & 611636 & 89867818 & 89925779 & $11 q 14.3$ & $\begin{array}{l}\mathrm{N} \text {-acetylated alpha-linked } \\
\text { acidic dipeptidase } 2\end{array}$ & $\begin{array}{l}\text { NAALADase activity. Inactivate the peptide neurotransmitter } \\
\text { N-acetylaspartylglutamate }\end{array}$ \\
\hline CHORDC1 & 604353 & 89933597 & 89956532 & $11 q 14.3$ & $\begin{array}{l}\text { Cysteine and histidine-rich } \\
\text { domain (CHORD) containing } 1\end{array}$ & Function of the wildtype gene in nematode development \\
\hline FAT3 & 612483 & 92085262 & 92629636 & $11 q 14.3$ & $\begin{array}{l}\text { FAT tumor suppressor } \\
\text { homolog } 3 \text { (Drosophila) }\end{array}$ & Cell adhesion \\
\hline MTNR1B & 600804 & 92702789 & 92715948 & $11 q 14.3$ & Melatonun receptor 1B & Receptor for malatonin, proton-coupled receptors \\
\hline C11orf75 & 609477 & 93211638 & 93276546 & $11 \mathrm{q} 21$ & $\begin{array}{l}\text { Chromosome } 1 \text { open reading } \\
\text { frame } 75\end{array}$ & \\
\hline TAF1D & 612823 & 93469095 & 93474703 & $11 q 21$ & TATA box binding protein & $\begin{array}{l}\text { Component of the transcription factor SL1/TIF-IB complex. } \\
\text { Downregulation induced apoptotic cell death }\end{array}$ \\
\hline MED17 & 603810 & 93517405 & 93546496 & $11 q 21$ & Mediator complex subunit 17 & Mammalian mediator of transcriptional regulation \\
\hline PANX1 & 608420 & 93862094 & 93915139 & $11 \mathrm{q} 21$ & Pannexin & $\begin{array}{l}\text { Structural component of the gap junctions and the } \\
\text { hemichannels }\end{array}$ \\
\hline GPR83 & 605569 & 94110477 & 94134585 & $11 q 21$ & G protein-coupled receptor 83 & Orphan receptor \\
\hline MRE11A & 600814 & 94150466 & 94227040 & $11 q 21$ & $\begin{array}{l}\text { MRE11 meiotic recombination } \\
11 \text { homolog A }\end{array}$ & $\begin{array}{l}\text { Double-strand break repair, DNA recombination, } \\
\text { maintenance of telomere integrity and meiosis }\end{array}$ \\
\hline FUT4 & 104230 & 94277017 & 94283064 & $11 q 21$ & $\begin{array}{l}\text { Fucosyltransferase } 4 \text { (alpha } \\
(1,3)) \text { myeloid-specific }\end{array}$ & Biosynthesis of lewis antigene \\
\hline PIWIL4 & 610315 & 94300474 & 94354587 & $11 \mathrm{q} 21$ & Piwi-like 4 (Drosophila) & Development and maintenance of germline stem cells \\
\hline KDM4D & 609766 & 94706845 & 94732678 & $11 q 21$ & $\begin{array}{l}\text { Lysine }(K) \text {-specific } \\
\text { demethylase } 4 D\end{array}$ & Histone coding \\
\hline SRSF8 & 603229 & 94800056 & 94804388 & $11 \mathrm{q} 21$ & $\begin{array}{l}\text { Serine/arginine-rich splicing } \\
\text { factor } 8\end{array}$ & Involved in pre-mrna alternative splicing \\
\hline SESN3 & 607768 & 94906113 & 94964246 & $11 q 21$ & Sestrin 3 & Normal regulation of blood glucose, insulin resistance \\
\hline CEP57 & 607951 & 95523642 & 95565854 & $11 q 21$ & Centrosomal protein $57 \mathrm{kda}$ & Required for microtubule attachment to centrosomes \\
\hline MTMR2 & 603557 & 95566044 & 95657371 & $11 \mathrm{q} 21$ & Myotubularin related protein 2 & Tyrosine phosphatase \\
\hline MAML2 & 607537 & 95711440 & 96076344 & $11 q 21$ & Mastermind-like 2 (Drosphila) & Transcriptional coactivator for NOTCH proteins \\
\hline JRKL & 603211 & 96123158 & 96126727 & $11 q 21$ & Jerky homolog-like (mouse) & Not yet defined, probably nuclear regulatory protein \\
\hline
\end{tabular}




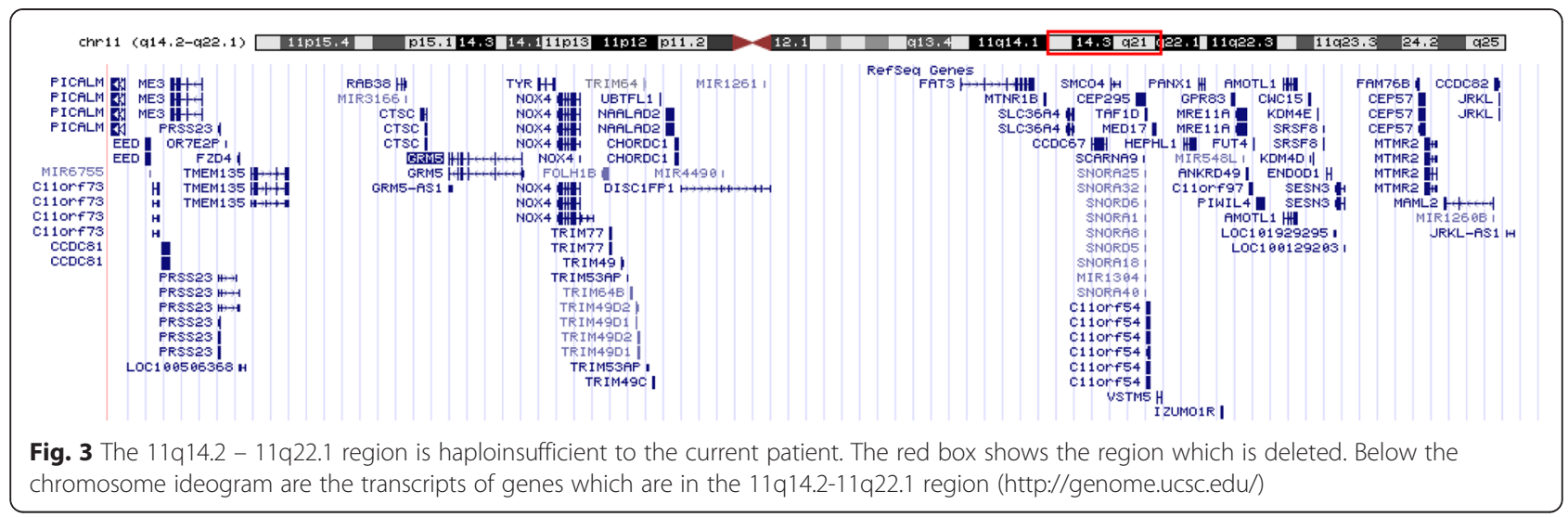

the hippocampus [30, 31]. Several neurological and neurodevelopmental disorders are associated with an abnormal function of this gene such as Fragile X syndrome, Schizophrenia anxiety, depression, and addiction [32-34]. All cases which overlaps our case, and in which the deletion includes this gene region, presents developmental delay.

There are four other cases in which developmental delay was present but the region containing this gene was not deleted $[16,19,20,25]$. However, the region deleted in this four cases includes another Glutamate receptor family gene in 11q22.3 GRIA4 (Glutamate Receptor Ionotrophic Ampa 4) that mediates fast synaptic excitatory neurotransmission (OMIM 138246) and this gene is also implied in neurological disorders in mice [35].

The patients who had normal development had no copy-number variations of both GRM5 and GRIA4 genes
$[6,8,17]$. Only in the case described by Sparkes et al. [11], resulted a normal development despite the GRIA4 gene deletion. When the deletions included both genes, there was a more severe phenotype [20, 21]. We hypothesize that both these genes could be associated with developmental delay in $11 \mathrm{q}$ interstitial deletions.

The remaining features were impossible to be correlated with any genotype because the deletions in different cases seem to generate many different phenotypes. These chromosomal deletions generally involve a large number of genes, but most of these genes are not dosage sensitive and a single copy of the gene ensures its function. In this situation, when a clinical phenotype was observed, would always be appropriate to analyze the genes on the intact chromosome in order to find mutations. Another mechanism could be the presence

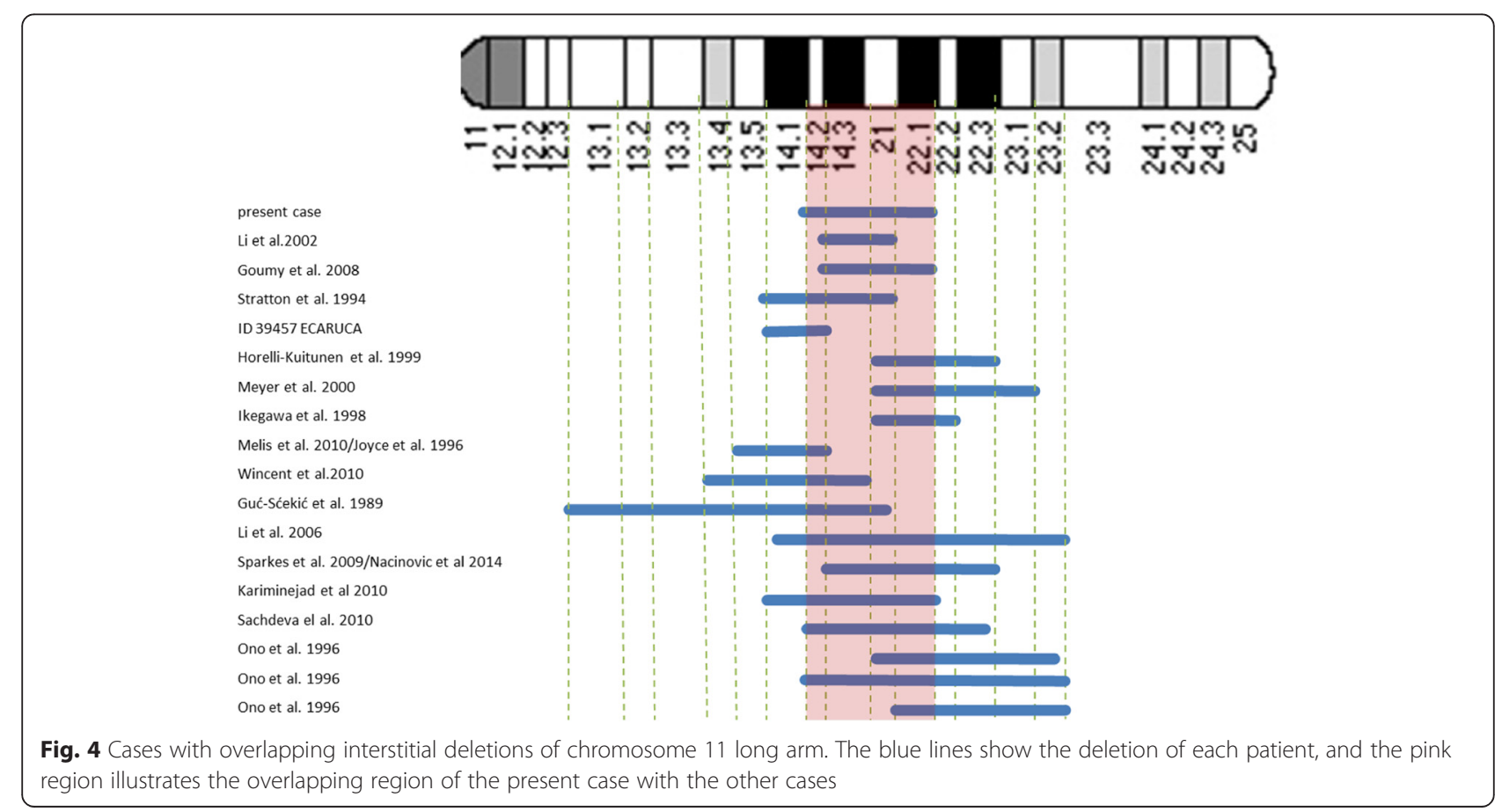


Table 2 Genotypes and phenotypic features of the present case and of the 19 cases with overlapping interstitial deletions of chromosome 11 long arm

\begin{tabular}{|c|c|c|c|c|c|c|c|c|c|c|c|c|c|c|c|c|c|c|c|c|c|}
\hline chromosomal & gion & 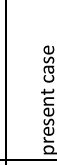 & 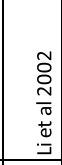 & 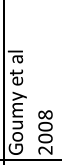 & 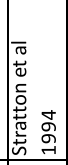 & 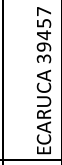 & 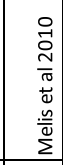 & 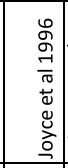 & 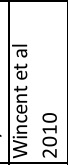 & 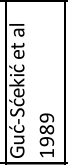 & 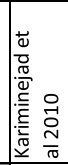 & $\begin{array}{l}\stackrel{0}{0} \\
\stackrel{N}{0} \\
\frac{\pi}{\pi} \\
\stackrel{0}{\Xi}\end{array}$ & 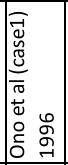 & 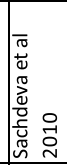 & 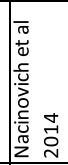 & 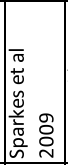 & 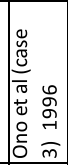 & 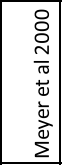 & 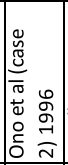 & 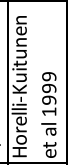 & 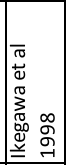 \\
\hline 13.1 & & & & & & & & & & & & & & & & & & & & & \\
\hline 13.2 & & & & & & & & & & & & & & & & & & & & & \\
\hline 13.3 & & & & & & & & & & & & & & & & & & & & & \\
\hline 13.4 & & & & & & & & & & & & & & & & & & & & & \\
\hline 13.5 & & & & & & & & & & & & & & & & & & & & & \\
\hline 14.1 & & & & & & & & & & & & & & & & & & & & & \\
\hline 14.2 & & & & & & & & & & & & & & & 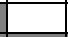 & & & & & & \\
\hline 14.3 & & & & & & & & & & & & & & & & & & & & & \\
\hline 21 & & & & & & & & & & & & & & & & & & & & & \\
\hline 22.1 & & & & & & & & & & & & & & & & & & & & & \\
\hline 22.2 & & & & & & & & & & & & & & & & & & & & & \\
\hline 22.3 & & & & & & & & & & & & & & 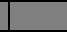 & & & & & & & \\
\hline 23.1 & & & & & & & & & & & & & & & & & & & & & \\
\hline 23.2 & & & & & & & & & & & & & & & & & & & & & \\
\hline growth retard & & & & & & & & & & $\mathrm{v}$ & & $v$ & $\mathrm{v}$ & v & v & & $\mathrm{v}$ & & & $\mathrm{v}$ & v \\
\hline brain anomali & & & & & & & & & & & & & & $\mathrm{v}$ & & $v$ & $\mathrm{v}$ & & & $\mathrm{v}$ & \\
\hline cranial dismor & & & & & $\mathrm{v}$ & & & & $\mathrm{v}$ & & $\mathrm{v}$ & $v$ & & & & & & & & $\mathrm{v}$ & \\
\hline genital anoma & & & & & & $\mathrm{v}$ & $v$ & & $v$ & & & & & & & & & & & & \\
\hline kidney anoma & & & & & $\mathrm{v}$ & & & & & & & & & $\mathrm{v}$ & & & & & & $\mathrm{v}$ & \\
\hline various dismc & hic facial features & $\mathrm{v}$ & & & & $\mathrm{v}$ & $\mathrm{v}$ & $v$ & $\mathrm{v}$ & $\mathrm{v}$ & $\mathrm{v}$ & $v$ & $\mathrm{v}$ & $\mathrm{v}$ & $\mathrm{v}$ & $v$ & $\mathrm{v}$ & $\mathrm{v}$ & & $\mathrm{v}$ & \\
\hline & hypertelorism & $\mathrm{v}$ & & & & & $v$ & & & $\mathrm{v}$ & & & & & & $v$ & $v$ & & $v$ & $\mathrm{v}$ & \\
\hline & ears anomalies & & & & & $v$ & $v$ & $v$ & $\mathrm{v}$ & $\mathrm{v}$ & & & & & & & $\mathrm{v}$ & $v$ & & $\mathrm{v}$ & \\
\hline & ghotic/submucous cleft palat & $t v$ & & & & & & & & $\mathrm{v}$ & & $v$ & $v$ & $\mathrm{v}$ & $\mathrm{v}$ & & $\mathrm{v}$ & $v$ & & & \\
\hline & micro/retrognathia & & & & & & & v & & v & & $v$ & & $\mathrm{v}$ & $v$ & & $v$ & $v$ & & & \\
\hline retinopathy / & & & & & & & $v$ & & & & & $v$ & $\mathrm{v}$ & $\mathrm{v}$ & & & & & $\mathrm{v}$ & & \\
\hline other skeletal & omalies & & & & & & $v$ & & & $v$ & & $v$ & & $\mathrm{v}$ & & $v$ & & & & $\mathrm{v}$ & $v$ \\
\hline short stature & & & $v$ & & & & & & & & $v$ & & & & & & & & & & $\mathrm{v}$ \\
\hline hypotonia & & & & & & & & & v & & v & & & & & & & & & v & \\
\hline seizures & & & & & & & & & $\mathrm{v}$ & & & & $v$ & $\mathrm{v}$ & & & $\mathrm{v}$ & & $v$ & & \\
\hline development & elay & MR & mild & & $\bmod$ & mild & $\bmod$ & $\bmod$ & $\bmod$ & v & $\mathrm{v}$ & $v$ & MR & MR & $\mathrm{v}$ & & MR & $v$ & MR & mild & \\
\hline attention defi & disorders/hyperactivity & $\mathrm{v}$ & $v$ & & & & $\mathrm{v}$ & & $\mathrm{v}$ & & & $v$ & & & & & & & & & \\
\hline
\end{tabular}

of copies or similar genes located elsewhere in the genome that show a compensatory gene expression. Also a deletion within a region subject to genomic maternal or paternal imprinting might not cause pathological phenotype. Therefore further work should be done in animal model organisms in order to fully understand the function of these genes and the pathways that contribute to the phenotype.

\section{Conclusion}

On the basis of current literature we are not yet able to define a monosomy $11 \mathrm{q}$ phenotype. Many other studies and accurate molecular characterization are needed to understand the complex genetic and environmental relationship that underlie the phenotypic differences observed in similar cases of chromosomal rearrangements.

\section{Consent}

Written informed consent was obtained from the patient for publication of this Case report and any accompanying images. A copy of the written consent is available for review by the Editor-in-Chief of this journal.

\section{Abbreviations}

ACGH: Array comparative genomic hybridization; HC: Head circumference; CNV: Copy number variation.

\section{Competing interests}

The authors declare that they have no competing interests.

\section{Authors' contributions}

VP, ES and RM wrote the manuscript; LT referred the patient for study; LT coordinated the clinical analysis of the patient; EM and ES performed the cytogenetic analysis; IP and SO signed out the molecular cytogenetic results; NP, SS, AG and SS performed prenatal ultrasound scan; and IP and EM coordinated the study. All authors have read and approved the manuscript.

\section{Acknowledgments}

The authors would like to thank the members of the family of the patient for their collaboration.

\section{Author details}

${ }^{1}$ Access to genome P.C., Clinical Laboratory Genetics, 33A Ethn. Antistaseos str, 55134 Thessaloniki, Greece. ${ }^{2}$ Department of Medical Genetics, University of Cagliari, Binaghi Hospital, Cagliari, Italy. ${ }^{3}$ Department of Obstetrics and Gynecology, University Hospital of Heraklion, Heraklion, Crete, Greece. ${ }^{4}$ Embryoiatriki-genetiki Ltd, 49 Kifisias Ave., Athens, Greece. ${ }^{5}$ Department of Gynecology, Larissa Medical School, University of Thessaly, Larissa, Greece. ${ }^{6}$ Developmental Assessment Unit, Second Department of Paediatrics, P\&A Kyriakou Children's Hospital, University of Athens, 11527 Athens, Greece.

Received: 18 July 2015 Accepted: 10 September 2015

Published online: 17 September 2015 


\section{References}

1. Coldren CD, Lai Z, Shragg P, Rossi E, Glidewell SC, Zuffardi O, et al. Chromosomal microarray mapping suggests a role for BSX and Neurogranin in neurocognitive and behavioral defects in the 11q terminal deletion disorder (Jacobsen syndrome). Neurogenetics. 2009;10:89-95.

2. Mattina T, Perrotta CS, Grossfeld P. Jacobsen syndrome. Orphanet J Rare Dis. 2009;4:9.

3. McPherson $\mathrm{E}$, Meissner L. 11q-syndrome: review and report of two cases. Birth Defects Orig Artic Ser. 1982;18:295-300.

4. Klep-de Pater JM, de France HF, Bijlsma JB. Interstitial deletion of the long arm of chromosome 11. J Med Genet. 1985;22:224-6.

5. Taillemite $\mathrm{J}$, Morlier BG, Roux C. Interstitial deletion of the long arm of one 11 chromosome. Ann Genet. 1975;18:61-3.

6. Goumy C, Gouas L, Tchirkov A, Roucaute T, Giollant M, Veronèse L, et al. Familial deletion 11q14.3-q22.1 without apparent phenotypic consequences: a haplosufficient 8.5Mb region. Am J Med Genet A. 2008;146A:2668-72.

7. Krgovic D, Marcun Varda N, Zagorac A, Kokalj-Vokac N. Submicroscopic interstitial deletion of chromosome 11q22.3 in a girl with mild mental retardation and facial dysmorphism: Case report. Mol Cytogenet. 2011:4:17.

8. Li L, Moore P, Ngo C, Petrovic V, White SM, Northrop E, et al. Identification of a haplosufficient 3.6-Mb region in human chromosome 11q14.3- > q21. Cytogenet Genome Res. 2002;97:158-62.

9. Li P, Zhang HZ, Huff S, Nimmakayalu M, Qumsiyeh M, Yu J, et al. Karyotypephenotype insights from 11q14.1-q23.2 interstitial deletions: FZD4 haploinsufficiency and exudative vitreoretinopathy in a patient with a complex chromosome rearrangement. Am J Med Genet A. 2006;140:2721-9.

10. Melis D, Genesio R, Cozzolino M, Del Giudice E, Mormile A, Imperati F, et al. An emerging phenotype of proximal 11q deletions. Eur J Med Genet. 2010:53:340-3.

11. Sparkes RL, Shetty S, Chernos JE, Mefford HC, Micheil IA. Interstitial deletion of $11 \mathrm{q}$ in a mother and fetus: implications of directly transmitted chromosomal imbalances for prenatal genetic counseling. Prenat Diagn. 2009:29:283-6.

12. Wincent J, Schoumans J, Anderlid BM. De novo deletion of chromosome 11q13.4-q14.3 in a boy with microcephaly, ptosis and developmental delay. Eur J Med Genet. 2010:53:50-5.

13. Carnevale A, Blanco B, Grether P, Castillejos AR. Interstitial deletion of the long arm of chromosome 11. Ann Genet. 1987;30:56-8.

14. De Pater JM, Ippel PF, Bijlsma JB, Van Nieuwenhuizen O. Interstitial deletion 11q. Case report and review of the literature. Genet Couns. 1997;8:335-9.

15. Guć-Sćekić M, Pilić-Radivojević G, Mrdjenović G, Djurić M. Interstitial deletion of 11q. J Med Genet. 1989;26:205-6.

16. Horelli-Kuitunen N, Gahmberg N, Eeva M, Palotie A, Järvelä I. Interstitial deletion of bands 11q21-> 22.3 in a three-year-old girl defined using fluorescence in situ hybridization on metaphase chromosomes. Am J Med Genet. 1999;86:416-9.

17. Ikegawa S, Ohashi H, Hosoda F, Fukushima Y, Ohki M, Nakamura Y Pseudoachondroplasia with de novo deletion [del(11)(q21q22.2)]. Am J Med Genet. 1998:77:356-9.

18. Joyce CA, Zorich B, Pike JS, Barber JCK, Dennis NR. Williams-Beuren syndrome: phenotypic variability and deletions of chromosome 7, 11, and 22 in a series of 52 patients. J Med Genet. 1996;33:986-92.

19. Meyer MF, Gerresheim F, Pfeiffer A, Epplen JT, Schatz H. Association of polycystic ovary syndrome with an interstitial deletion of the long arm of chromosome 11. Exp Clin Endocrinol Diabetes. 2000;108:519-23.

20. Ono J, Hasegawa T, Sugama S, Sagehashi N, Hase Y, Oku K, et al. Partial deletion of the long arm of chromosome 11: ten Japanese children. Clin Genet. 1996;50:474-8.

21. Sachdeva R, Sears JE, Rychwalski PJ. A novel case of bilateral high myopia, cataract, and total retinal detachment associated with interstitial 11d deletion. Ophthalmic Genet. 2010;31:84-8.

22. Stratton RF, Lazarus KH, Ritchie EJ, Bell AM. Deletion (11)(q14.1q21). Am J Med Genet. 1994:49:294-8.

23. Syrrou M, Fryns JP. Interstitial deletion of chromosome 11 (q22.3-q23.2) in a boy with mild developmental delay. J Med Genet. 2001;38:621-4.

24. Wakazono A, Masuno M, Yamaguchi S, Tsubouchi K, Kondo N, Orii T. Interstitial deletion of the long arm of chromosome 11: report of a case and review of the literature. Jpn J Hum Genet. 1992:37:229-34.

25. Nacinovich R, Villa N, Redaelli S, Broggi F, Bomba M, Stoppa P, et al. Interstitial $11 \mathrm{q}$ deletion: genomic characterization and neuropsychiatric follow up from early infancy to adolescence and literature review. BMC Res Notes. 2014:7:248.

26. Kariminejad A, Kariminejad R, Tzschach A, Najafi H, Ahmed A, Ullmann R, et al. 11q14.1-11q22.1 deletion in a 1-year-old male with minor dysmorphic features. Am J Med Genet A. 2010;152A:2651-5.

27. Vincent AM, Maiese K. The metabotropic glutamate system promotes neuronal survival through distinct pathways of programmed cell death. Exp Neurol. 2000;166:65-82

28. Auerbach BD, Osterweil EK, Bear MF. Mutations causing syndromic autism define an axis of synaptic pathophysiology. Nature. 2011:480:63-8.

29. National Center for Biotechnology Information. www.ncbi.nlm.nih.gov/ gene/2915. Accessed 5 Jul 2015

30. Xu J, Zhu Y, Contractor A, Heinemann SF. mGluR5 has a critical role in inhibitory learning. J Neurosci. 2009;29:3676-84.

31. Lu YM, Jia Z, Janus C, Henderson JT, Gerlai R, Wojtowicz JM, et al. Mice lacking metabotropic glutamate receptor 5 show impaired learning and reduced CA1 long-term potentiation (LTP) but normal CA3 LTP. J Neurosci. 1997;17(13):5196-205.

32. Dölen G, Bear MF. Role for metabotropic glutamate receptor 5 (mGluR5) in the pathogenesis of fragile X syndrome. J Physiol. 2008;586:1503-8.

33. Conn PJ, Lindsley CW, Jones CK. Activation of metabotropic glutamate receptors as a novel approach for the treatment of schizophrenia. Trends Pharmacol Sci. 2009;30:25-31

34. Slassi A, Isaac M, Edwards L, Minidis A, Wensbo D, Mattsson J, et al. Recent advances in non-competitive mGlu5 receptor antagonists and their potential therapeutic applications. Curr Top Med Chem. 2005:5:897-911.

35. Beyer B, Deleuze C, Letts VA, Mahaffey CL, Boumil RM, Lew TA, et al. Absence seizures in $\mathrm{C} 3 \mathrm{H} / \mathrm{HeJ}$ and knockout mice caused by mutation of the AMPA receptor subunit Gria4. Hum Mol Genet. 2008;17:1738-49.

\section{Submit your next manuscript to BioMed Central and take full advantage of:}

- Convenient online submission

- Thorough peer review

- No space constraints or color figure charges

- Immediate publication on acceptance

- Inclusion in PubMed, CAS, Scopus and Google Scholar

- Research which is freely available for redistribution 